\title{
Barry Mauer's Deadly Delusions: Right-Wing Death Cult
}

\author{
Jen Senko \\ Director, "The Brainwashing of My Dad"
}

Mauer, Barry. Deadly Delusions: Right-Wing Death Cult. The Governors of the State of Florida Press, 2020.

Deadly Delusions, written in 2020 , is prescient in some ways and is an important piece of work. While reading it, I was thinking this could be me writing this book, except it is much better articulated. It examines thoroughly many of the aspects of the right-wing phenomenon. Many fail to see the right-wing media machine and ideology for the deadly threat it is. Mauer attributes this to the rise in anti-intellectualism and anti-science due to right-wing organizations coinciding with domains of journalism and education. Of course, now after the attempted coup on the Capitol building on January 6, 2021 it has finally become a red flashing light. Writing his book before this incident, Mauer said, "we need a wake-up call" $(2020,1)$. We got one on January 6 - waking most people up, although some of the extremists on the right play it down and some even condone it. Mauer examines the delusions of the right-wing through the lens of his students. He then rightfully attributes the right-wing death cult to the suicide of human civilization. He diagnoses the condition and recommends decisive action. Mauer's book is accessible to a mixed audience: both the general population (although it would most likely seem biased to those on the right) and to an academic-based audience. This is because of the direct-nature of his approach and its simplicity. It is in part accessible to a general audience also because of his unique experience as a teacher and more specifically, due to his location, the right-wing background of many of his students. He has the direct and unique experience to draw from.

Mauer found learning disorders in his students were caused by right-wing ideology. In order to dig deeper he created a questionnaire for them about their beliefs. He gives many instances of some of their sometimes absurd and alarmingly incorrect beliefs. Among some of them: $41 \%$ believe the Nazis were left-wing. $44 \%$ believe that gun control leads to tyranny, $41 \%$ believe the U.S. found WMD when we invaded Iraq, $52 \%$ believe the deficit increased under Obama, 22\% believe there is a liberal war on Christmas, 59\% believe Saddam Hussein was collaborating with Al Qaeda, 44\% believe that torture works, 11\% believe Obamacare created death panels, and that the federal government is preparing to seize guns and put patriots in FEMA camps, and climate change is a hoax perpetrated by liberals and scientists so they can make money and increase government control, 30\% believe that Planned Parenthood sells fetus parts for profit, $11 \%$ believe the biblical flood created the Grand Canyon, and $96 \%$ of them said they vote in elections (2020, 2-3). And that's what makes the right-wing echo chamber dangerous. The misinformation it creates causes people to vote against their own interests and those of roughly $90 \%$ of their countrymen and women. It also limits their inability to understand the world in a comprehensive way. They see everything through the lens of this disinformation. 
Mauer defines "eliminationist rhetoric" and explains how it drives some people to their threshold and then, to commit violence. Eliminationist rhetoric can lead to genocide. For an example of the power of eliminationist rhetoric he reminded us of the genocide that occurred in Nazi Germany and Rwanda where in both cases eliminationist rhetoric and dehumanizing of the targeted group was broadcast daily to tens of millions of people. Eliminationist rhetoric dehumanizes the victim and thereby the revulsion to murder is more readily overcome. An anti-defamation league report (here in the U.S) concluded that between 2009 and $2018,73 \%$ of the extremistrelated murders were committed by right-wing extremists $(2020,15)$. Mauer emphasizes there is no similar phenomenon on the left. The right has been using it for years. Violence is more common among right-wing groups because they are more authoritarian. He describes the mainstream right-wing as a murder-suicide cult, especially when it comes to COVID-19. One right-wing pastor, Tony Spell, told his congregation that "True Christians don't mind dying of COVID-19 if they are infected at church." Mauer presciently said, "When Trump glorifies violence against perceived enemies, his followers attack protesters, minorities, and journalists with glee" (2020, 11). Other right-wing leaders encourage murderous rage using contrived grievances: millions voted illegally (for Democrats, of course), Hillary Clinton runs a child sex-ring, Mexican immigrants are rapists, etc. He describes how these lies become mass delusions and result in destructive acts. He cites how since conservatives generally have greater fear and revulsion responses, their brains make good hosts for delusional beliefs. He reminds us eliminationist rhetoric used to be limited to fringe groups but since right-wing radio, it moved mainstream. He feels our current situation parallels the pre-genocide stages of Nazi Germany and 1994 Rwanda. I agree. The type of eliminationist rhetoric Glenn Beck has used, for example, includes calling progressives "a cancer," "the disease that's killing us," a "virus," a "parasite," "snakes," "cockroaches," and "vampires" who are intent on destroying the Constitution $(2020,12)$. Mauer asks the question: how strong is the link between right-wing rhetoric and murder? He cites a nationwide review by ABC News which identified at least 36 criminal acts directly in connection with Mr. Trump when he was president $(2020,13)$. Mauer is spot on when attributing violence to the eliminationist rhetoric coming from the right-wing over decades (not just by Trump). A look at what happened at the Capitol on January 6 is just that - resulting from years and years of describing anyone who is not right-wing - which evolved in 4 years into not worshipping Trump - as traitors and evil human beings not worthy of life itself. Fascism is what Mauer equates the right-wing movement of today with. He quotes Umair Haque who writes, "Fascism... is not mere religion, heritage, or racism. It is the organized institutionalization of supremacist violence, with the aim of taking over all a country's branches of government and reshaping them to become tools of mass oppression and subjugation so that the pure and true reign over the dirty and filthy subhumans... who are lucky if they are even allowed to live as slaves" $(2020,18)$.

Mauer says that incidents like the 36 criminal acts identified by ABC News constitute stochastic terrorism, with violence merely implied. He uses the example of King Henry II of England who says, "Will no one rid me of this turbulent priest," or of a mafia boss who might say something like, "it'd be a shame if something happened to Fat Dom or Freddy Fishface." Mauer also describes the term scripted violence, in which a person with a national platform identifies the targets and leaves it up to the listeners to figure out what the action should be $(2020,14)$. Hate radio hosts like Alex Jones will give addresses of people he would like to see harassed by way of 'just mentioning them' and telling his audience what he believes they are guilty of - such as in the Sandy Hook shooting being a false flag. He leaves it up to his listeners to carry out the violence. Trump often used the rightwing strategy of deniability by saying he was joking, but it was never funny. Scripted violence could also be used to describe Donald Trump's speech on January 6, riling up the angry mob who, after were told to march to the capitol, then breached it, created bedlam and carried out the violence. I would say it was the result hoped for by Mr. Trump. He identified the target and left it up to the mob to carry it out. 
Using terms such as "delusional," "cult," and "evil" may be necessary when dealing with this ideology $(2020,23)$. Mauer says prohibiting these terms will hobble our investigations and interventions. He quotes Martin Longman, who writes, "It's truly the worst of all worlds when Nazis suddenly feel free to be Nazis, and at the same time a lot of other people begin to accommodate themselves to beliefs they never before held or felt the need to tolerate" $(2020,23)$. Calling a duck a duck is vital as he describes right-wing leaders as having Social Dominance Orientation (SDO), meaning "they want a steep hierarchy with themselves at the top" and describes this as perfect breeding ground for cults $(2020,24)$. I would argue that it looks like millions of Trump followers are now "cultified." As Mauer explains, those that follow the right-wing ideology feel no moral obligation outside their own families and comrades. Their allegiance is not to their country, but rather to each other, though they will claim it's to their country when convenient. They can compartmentalize and think of liberals, progressives, minorities, etc. as "subhuman." He does think that human consciousness is malleable, but not to all people. Some people when presented with conflicting evidence will dig in deeper to their beliefs. He feels they do so because they are often under the influence of someone - like an authority figure who taught them to think that way. I love it when Mauer says, "Plutocrats and religious-right leaders flood the infosphere with propaganda in support of the Republican Party and their agenda" $(2020,19)$. And then goes on to bluntly say that they happen to be the key beneficiaries of the right-wing belief system. We need more bluntness like Mauer's.

Mauer talks briefly about what we can do. He says we must not allow right-wing propagandists to hijack the media and distort worldviews. But those of us who confront it get accused of censorship. He says, "But allowing right-wing propaganda in journalism has led to dismediation, which destroys journalism as a trusted means of communication" $(2020,34)$. And that we need to oppose efforts at dismediation. He says in order to do this you must bear witness to right-wing abuses and media complicity by stating it publicly. For instance, naming the NRA a domestic terrorist organization was a good thing. Defend the collective cognitive immune system. He means we must help students develop and maintain a healthy cognitive immune system to protect them against pathological beliefs. Disabuse liberals that their opponents are not committed to evil. Support anti-bullying campaigns, antiterrorism, anti-fascism, and cult intervention. Never treat the right-wing or its leaders as just a joke. I think many used to do this, but since the attack on the Capitol, less so. Realize that right-wingers will use the best character traits of liberals and leftists against them. Many liberals are open-minded to a fault and refuse to see the terrifying reality of the right in America. They also want to be liked. Non-stop resistance. We have to fight back, if possible, non-violently, violently if necessary. Don't try to change their mind unless you are trained to do so. Don't try to find middle-ground with arsonists (as he describes them). Confront people who call themselves nonpolitical. That, he views as selfish. Confront postmodern relativists who believe there are no such things as truth, mental health, or morality - because these are "constructs." And he believes any hope of recovery from this catastrophic state we're in needs eternal vigilance and a program of justice (2020, 36-39).

After the introduction, Mauer turns to a cartoon-design, where he reiterates most of what he discusses in the first part of his book, but clarifies, summarizes, and expands on some of the ideas he covered. The cartoons are largely made up of pictures of Mauer and his horse, but altered or colored in such a way that it matches a modern cartoon-like style. In this section he is the teacher, so he is in many of the pictures saying the things he wants to point out. Or his horse says them or adds comments. (Animals are a sure-fire way to keep someone's attention.) He goes into several issues, one of which he calls the Roots of Denial. Those in denial use what he calls motivated reasoning. They see only what they want to see insofar as it matches their preconceived beliefs. This is in part because of the Law of Comfort. They want to be comfortable and feel good about themselves. The Law of Self Esteem: cognitive dissonance causes a personality crisis. An important point to understanding a conservative 
mindset is their need to have answers neatly wrapped up, to have closure and to get rid of discomfort. They are not comfortable with uncertainty. They want things to be resolved into a firm belief. This is Mauer's view of and the explanation of the conservative mind-set.

The great thing about the cartoon section is that it is akin to soundbites. With people's attention spans being limited from our $24 / 7$ social media and with the learning disorders some of his students have which he says is from their adherence to right-wing ideology (rejecting information that conflicts with their beliefs), he is able to pull the important parts of what we would read in say, a sentence or paragraph, out. Therefore, these cartoon balloons coming from him with statements such as "dangerous beliefs once limited to the fringe are now central to rightwing political discourse," or "right-wing leaders have integrated eliminationist sentiments into a mainstream ideology," for example, can live in our heads and be easily accessed in a conversation, or for an explanation to ourselves of something we are trying to understand. The cartoon section as a stand-alone is great for students and even as a coffee table book. The graphics alone could draw one in. Someone sitting in your living room could easily pick it up and learn some extremely important basics pertaining to the right-wing media machine and ideology. It could pique their interest. The reason for the cartoon book is that when Mauer initially submitted his findings in a research paper to a journal, he was accused of being biased for not being just as critical about leftwing discourse. The cartoon book was one way he was able to get around the bias of the journal. In some ways it could be seen as even more effective as he is able to create different and appropriate moods with the pictures and design effects. For example, one such picture is a head of Rush Limbaugh looking insane and foreboding. It simply injects some humor and the pictures alone tell their own story.

One idea he discusses is how we live and think by pictures in our head. I am not sure if it's accurate to state that so broadly. Perhaps too much importance is placed on his discussion of "pictures in our heads." It's a little vague and not easily imagined. He talks about how Walter Lippman manipulated images because he understood the importance of images and thus that is relevant where we do have pictures in our heads. We are fed impressions all of our lives, but they usually result in determinative statements and beliefs. I think "pictures in our heads" are just a part of that and another way we arrive at being who we are. I think it would be more accurate to say we live by both, words, phrases, statements from what we hear from our teachers, parents, media figures or friends, and by pictures in our heads. It might be too broad to imply that we solely live and think by pictures in our heads.

As Mauer stresses, never treat the right-wing or its leaders as a joke. Pundits and many in the media for years treated right-wing media as just silly entertainment - not a serious threat to be reckoned with. Now it's plain for every person honest with themselves to see how dangerous the right-wing media and its brainwashed audience can be. That is not to say that all who consume right-wing media are brainwashed or dangerous, but there is a large number of those that do consume it that have become violent and radicalized. Those that aren't violent are seriously disinformed which, because they are motivated by extreme anger caused by this disinformation, vote and that affects the health, stability, and policies of our country. The problem is that media, like doctors, are often afraid to criticize other media. They are also afraid of being accused of liberal bias. And politicians are afraid to call right-wing media out because they don't want to be attacked by it - or even accused by the right or the left of not respecting our first amendment. It is not often enough that right-wing media is not clearly blamed for this division in our country and the breeding of so many domestic terrorists. Mauer's book makes clear in its straightforward and blunt approach how urgent it is for us to address this issue. He tackles the issue from every side, from how the disinformation has trickled down and deceived his students, to how dangerous it can be to society as a whole and what we can and can't do about it. 


\section{Cite this Essay}

Senko, Jen. "Barry Mauer's Deadly Delusions: Right-Wing Death Cult." Rhizomes: Cultural Studies in Emerging Knowledge, no. 37, 2021, doi:10.20415/rhiz/037.r04

RHIZOMES ISSN 1555-9998 ^ 230 East Hall Bowling Green State University Bowling Green, OH 43403

Editors: Ellen Berry and Carol Siegel. Reviews editor: Craig J. Saper. Technical editor: Helen J Burgess 